\title{
PERCEPTION AND EXPECTATION OF EFL STUDENTS ON IDEAL ONLINE LEARNING: A SURVEY STUDY IN AN INDONESIAN ISLAMIC HIGHER EDUCATION
}

\author{
Soni Ariawan \\ English Language Education Study Program, Faculty of Education and Teacher Training, \\ State Islamic University of Mataram, Indonesia \\ soniariawan@uinmataram.ac.id
}

Received $\quad: 12 / 12 / 2021$

Accepted $\quad: 16 / 12 / 2021$

Publication $\quad: 17 / 12 / 2021$

\begin{abstract}
Online learning during Covid-19 pandemic has enabled teachers and students interact remotely. Several technological tools have generated toward an effective online learning such as Moodle, Schoology, Google Meet and Google Classroom. The present study is aimed to investigate EFL students' perception on the use of Google Classroom as an online learning platform and their expectation on ideal online learning. 112 EFL students at State Islamic University of Mataram responded to the survey study designed with open-ended questions. Students' responses were qualitatively analyzed to find the main themes and sub-themes. The finding reveals that most students, $67 \%$, perceived the use of Google classroom negatively due to the potential problems such as technical and financial problems that lead to misunderstanding on materials delivered by the teachers. On the other hand, $27 \%$ of the students positively perceive the ease of use and its flexibility and accessibility. The least perception from the students is neutral, especially those who play safe by perceiving the perception from both positive and negative sides. Furthermore, the students proposed an ideal online learning that employs an effective teaching method and curriculum, provides such complete facilities, and combines both online and offline mode (blended learning).
\end{abstract}

Keywords - EFL students, perception, expectation, ideal online learning

\section{Introduction}

The profound impact of Covid-19 pandemic affects health and economic sector, on how people live and work, and the education sector, on how they learn, which is considered the most important challenge (OECD, 2020). Schools and universities' disclosures due to the Covid-19 pandemic have also affected the mode of teaching and learning. Transformation and adaption on curriculum, teaching method and strategy, and assessment are needed. The government of Indonesia directed all schools and universities to online learning by generating technology to create an online Learning Management System (LMS). Some universities such as the State Islamic University of Mataram tried to find the most appropriate LMS and applied a very simple way of online learning through WhatsApp to begin learning transformation due to the Covid-19 outbreak. However, the following semester was better as the learning had been changed to Google Classroom rather than WhatsApp based learning, and currently, it has been being transformed to Moodle. This online learning has no longer been a core business for universities only as it has been systematically integrated into students' learning experience through the contextual curriculum (Ellis et al., 2009).

One year-online learning means a lot to students and teachers to generate technology to exponentially develop a learning management system and digital learning environment in higher education (Fedynich et al., 2015). It has been supported by the nature of millennial learners who are interested in exploring learning through technology (Subandi et al., 2018) as they have been exposed 
to the information technology and digital era from a very young age compared to any prior generation (Roehl et al., 2013). The millennial perceive technology as a challenge and opportunity rather than a problem (Werth \& Werth, 2011). They function internet and technology for learning and for managing their lives (Pullan, 2009). It is why they are very adaptable to follow the learning activities in the online environment. They just need to be introduced and directed to the operational steps of learning in a learning management system.

On the other hand, a quick adaptation especially for "manual teachers or lecturers" is urgently needed. They have to upgrade their technological skill and combine it with pedagogical skill toward technology-based learning. The fact shows that many of them find it difficult to reform the teaching method and style to online learning as they are not familiar with the technological integration in teaching. If the teachers enjoy employing traditional teaching techniques and they would not develop their technological skill and bring it to the class, the future of online learning is not strong in the near future (McConnell, 2018). It is why teachers play a pivotal role toward the quality of online learning and incorporate active learning strategies to engage their students (Roehl et al., 2013). Teachers are standing on a dilemma on how to realize the same quality of online learning as face-to-face learning. One of the main challenges is designing an online learning environment that can increase students' participation, motivation, self-discipline and autonomy (Rojabi, 2020).

One more condition of online learning, which is contradictive with the explanation mentioned above, is when an online learning system sounds familiar for teachers because they might have got the training or capacity building, but the students may do not understand how to follow the learning. In this matter, teachers have to pay attention to online learning implementation whether the students perceive, access, or react positively or negatively which really depends on where online learning takes place and who the students are (Agung et al., 2020). Teachers need to have excellent online teaching skills and techniques that consist of incredible domain knowledge, computer knowledge, communication skills, clarity of expression, emotional connection with students and the ability to overcome both technical and substantial issues during online class (Mishra et al., 2020). In terms of communication, Aydin et al., (2015) strikes a significant point saying that communication between teachers and students is a basic effect that may shape students' perception and approach in online learning.

Education technology, according to Dorf (1969), does not only include learning tools, it is further about educational resources, learning environments and learning methods that set the learning management system in online learning. In the current research, Google Classroom is the primary platform used by the lecturer. To sum up, the research aims to find out EFL students' perception of the use of Google Classroom during one-semester learning and to explore their expectations on ideal online learning according to their perspectives. This research is significantly needed to be a strong and relevant recommendation for future online learning and for decision makers of the higher educational institutions to have a better understanding of the effectiveness of using certain platform for their students (Al-Maroof \& Al-Emran, 2018). To conclude, educational landscape has been changed due to the existence of online learning environment where some students thrive in this learning environment, but the rest sometimes become less motivated and disengaged (Ferrer et al., 2020). It is interesting to investigate millennial students' perception and expectation as they are native technology, whether they have a positive or negative perception of online learning using Google Classroom.

\section{Literature Review}

Bentley et al. (2012) define online learning system or virtual learning system as an integration of teaching and learning process with internet connection. It means that the teachers urgently need technological-pedagogical knowledge and skill as they are encouraged to generate the internet toward an effective online learning management system. It is true that the key of success does not merely depend on the teachers. It is students who should increase their own motivation as well, but teachers act as a driver who is able to direct the students to the appropriate destination safely. However, several inevitable factors might influence the quality of online learning apart from students' internal problem. The factors include convenience, learners' characteristics and readiness, and real conditions that might shape the teaching quality (Van Wart et al., 2020). Those factors are related to the teachers' responsibility. They play essential roles for students' satisfaction whether teachers have successfully 
designed, delivered, and utilized the materials to improve students' motivation (Fedynich et al., 2015).

The ultimate roles of teachers is not restricted in transferring information and knowledge, rather they have to be facilitators, advisors, assessors, researchers, technologists, designers as well as manager-administrators (Goodyear et al., 2001). Therefore, teaching and learning online during Covid19 pandemic is an appropriate momentum for teachers in improving their professionalism, pedagogy, and digital competence so they can conduct a hybrid learning successfully (Rosita et al., 2020). The students need the existence of teachers or instructors during online learning because they need to feel connected and engaged with the teachers, so it is good to recommend teachers or instructors to participate in communication training dealing with communication practices, pedagogy and content delivery in the class (Kaufmann \& Vallade, 2020).

Many studies have explored the benefits of online learning that students think as an ideal online learning setting. Henderson et al., (2017) conducted a survey study on students' perspectives that they perceived Google classroom as the most useful or helpful digital technology in learning. He found that most students positively perceive digital technology as it might enable them to learn flexibly from one place to another, ease them arranging and managing tasks, and ease them review, replay, and revise digitally recorded materials provided by the lecturers. A study from Kumar et al.,(2020) also found that students perceived online learning positively in terms of three aspects: usefulness, ease of use and satisfaction of using it. More specifically, they claimed that a convenient accessibility through mobile application was the essential part of online learning especially using Google Classroom. It is also believed that Google Classroom was a cost-effective, easily accessible and user-friendly platform for online learning (Kumar \& Bervell, 2019). This finding is also by a study conducted by Apriyanti et al. (2019) where students find it easy and quick to access the learning content and they are benefited with the use of paperless online classroom. In addition, a study by Rojabi (2020) also reveals that online learning is something new for the students, so they are interested and motivated to comprehend the material. They show a positive engagement and enthusiasm. Furthermore, online learning benefits students in terms of being engaged in quantitative reasons either for first-year or senior students (Dumford \& Miller, 2018).

Apart from its ideal perspective (positive perception), a study by Mulyani et al. (2021) reveals almost the same percentage of students who have negative impressions and positive impressions of online learning. The students mention internet network, high need of internet quota, limitation of material explanation and absorption, and the influence from social media as the challenges of online learning. Even though online learning may increase students' motivation, but it cannot provide better experience and productivity in achieving the learning outcomes or required competencies, even they are still reluctant if online learning will be learning mode in the future (Syauqi et al., 2020). In terms of distraction, many students argue that their dissatisfaction with online learning due to a distraction reduces their focus and leads to psychological and management issues (Maqableh \& Alia, 2021). Furthermore, studies also reveal that online collaborative learning environments can have cognitive, social, psychological, and technological disadvantages, including mechanical errors, conflict, fear, discomfort, and time wasted on technological problems (Lin \& Griffith, 2014). In term of students' behavior, it is confirmed that online learning may result an academic procrastination which is a complex phenomenon in online learning (Cheng \& Xie, 2021). It is possibly caused by lack of motivation and self-efficacy from the students. These factors will lessen their engagement during learning. They were less likely to engage with teachers, school or faculty, and their counterparts that might result in differences compared to traditional face-to-face classroom (Dumford \& Miller, 2018). In short, most students have a negative perception of online learning and expect to study offline (faceto-face) rather than online in the future.

\section{Research Method}

The present study is designed quantitatively by developing a set of online questionnaire. A survey study is attempted to collect the data by distributing an online questionnaire to students' WhatsApp groups. There are three main items prescribed in the questionnaires: students' demography, perception, and expectations on ideal online learning. In addition, there are 112 EFL undergraduate students from State Islamic University of Mataram who filled out the distributed questionnaire items. They have experienced one-semester learning through Google Classroom. Therefore, it is crucial to 
investigate their perception as well as expectation on ideal online learning in the future through openended questionnaire items. Students' responses were coded and specified into three types of perception: positive, negative, and neutral. Each theme is displayed quantitatively after counting the frequency and the percentage. In terms of expectation, the responses were coded into three main themes: learning mode and system, effectiveness and creativity and facilities, and accessibility. The result of the coding is displayed in the table and described comprehensively.

\section{Results and Discussions}

There were 112 students who participated in the survey and most of them were male. The data also showed that participants came from different semester where most of them were from semester 7 with more than $40 \%$, semester 5 with $38.3 \%$ and semester 3 with just $19.1 \%$. Most of them were in the age of 21-24 and 17-20 years old. In terms of location, the entire students followed the class from home, where most of them lived in Lombok, and the rest were in Sumbawa and other regions around West Nusa Tenggara Province, Indonesia. The participants also confirmed on the most commonly used platform in their learning and they mostly recommended Google Classroom as the primary platform. In accordance with the university policy, it instructed all lecturers to generate Google Classroom as the main learning platform during the Covid-19 pandemic. The university had not developed a special learning management system yet to run the academic activities. The finding has already indicated that Google Classroom seems the most suitable learning platform both for lecturers and students, even though some lecturers tend to combine Google Classroom with mobile based platform such as WhatsApp. Students' demography can be seen from the table below.

Table 1: Respondents' Demography

\begin{tabular}{lcc}
\hline Item & F & P \\
\hline Gender & 77 & $67.8 \%$ \\
\hline Fale & 35 & $31.2 \%$ \\
\hline Age & & \\
\hline $17-20$ & 52 & $46.5 \%$ \\
\hline $21-24$ & 60 & $53.5 \%$ \\
\hline $25-27$ & & \\
\hline Semester & & $18.7 \%$ \\
\hline 3 & 21 & $38.4 \%$ \\
\hline 5 & 43 & $42.9 \%$ \\
\hline 7 & 48 & $91.1 \%$ \\
\hline Location & & $3.5 \%$ \\
\hline Lombok & 102 & $5.4 \%$ \\
\hline Sumbawa & 4 & \\
\hline Other places & 6 & $91.1 \%$ \\
\hline Most commonly used online platform & & $9.9 \%$ \\
\hline Google classroom & 102 & 0 \\
\hline WhatsApp & 11 & 0 \\
\hline Zoom & 0 & \\
\hline Other & 0 & \\
\hline
\end{tabular}

In terms of perception, the students have three main general perceptions: positive, negative and neutral. The result from the current study indicates that $67 \%$ students have negative perception, $27 \%$ students with positive perception and $6 \%$ of them perceive online learning from neutral perception. The researcher could not predict the current finding as the students, based on personal experience during the pandemic teaching, seem happy as they do not have to attend face-to-face class. It shows that teachers have to go beyond the facial expression and emoticon sticker sent by the students through Whatsapp or other communication media. The teachers need to do a qualitative investigation to capture their perspectives and expectations. 
To begin with, the main reason for having such negative perception is due to students' experience who found that learning English through Goggle Classroom was ineffective. They considered online learning as not attractive that might decrease students' interest and motivation in learning. This sort of perception potenially endangers the quality of learning because students will not be actively engaged to the learning. Consequently, there will be a gap among teachers and students toward effective learning where students find it confortable within such supportive learning. As stated by Dumford \& Miller (2018) in their research that lack of motivation and self efficacy tend to result in differences and miscommunication during the learning.

Furthermore, the students found it difficult to understand teachers' explanation on material delivered in the Google Classroom. It could be understood as GC is not interactively designed as a learning management system. It is true that teachers are able to share the materials and provide written explanation, however, interactive and collaborative space for teachers and students in the blackboard are not provided. It is possibly caused by lack of motivation and self-efficacy from the students. These factors will also lessen their engagement during learning.

Apart from substantial problems, students have negative perception due to technical and financial problems. Technical problems deal with the restriction and limitation of internet access due to instability of signal, internet provider trouble or the device problems. Finally, the students also criticized the affordability of learning online through Google classroom where some of them could not regularly buy internet data as they are struggling to earn money for living cost or other university payment. Mulyani et al., (2021) and Lin \& Griffith (2014) already mentioned in their findings that the demand of technological and technical disadvantages, internet network, high need of internet quota, limitation of material explanation and absorption seems to be potential constraints for the students toward an effective online learning.

Apart from its negativity, some students experienced useful learning in Google classroom. The ease of use, flexible and accessible learning, as well as effectiveness of learning during Covid-10 pandemic seems to be the major factors that lead to the positive perspectives. This finding is in accordance with a research from Henderson et al. (2017) and Kumar et al. (2020) where the students positively perceive the use of digital technology in learning because its flexibility, accessibility and the ease of use in arranging tasks and reviewing materials as well as replaying the recorded materials.

Another perception indicated from the respondents' voices was neutral perception where they argued that learning online through Google classroom brings both positive and negative sides to them. The keywords that appeared in their response were clarity and ease of use. Some of them found learning from Google classroom unclear in terms of teachers' explanation on materials, exercises and assignments. However, the ease of use seems to be a crucial reasons why they are in favor learning online in Google classroom.

Table 2: Students' perception on online learning

\begin{tabular}{|c|c|c|c|}
\hline Perception & Reasons & Frequency & Percentage \\
\hline \multirow{5}{*}{ Negative } & Costly & 6 & $5 \%$ \\
\hline & Difficult to understand & 28 & $25 \%$ \\
\hline & Ineffective & 34 & $30 \%$ \\
\hline & No access & 2 & $2 \%$ \\
\hline & Unattractive & 5 & $4 \%$ \\
\hline \multirow{3}{*}{ Positive } & Easy and insightful & 10 & $9 \%$ \\
\hline & Effective and suitable & 18 & $16 \%$ \\
\hline & Relaxed and flexible & 2 & $2 \%$ \\
\hline \multirow[t]{2}{*}{ Neutral } & Easier but unclear & 7 & $6 \%$ \\
\hline & Total & 112 & $100 \%$ \\
\hline
\end{tabular}

The second research problem that aims to address in the present study is the students' expectation on an ideal online learning. The open-ended questions are designed to gauge their perspectives from various points of view such as teacher, learning mode, system, methodology as well as facility. Interestingly, students suggested that an effective and creative teaching method and materials should be primarily considered toward an ideal online learning. This finding seems pivotal to 
the teachers and educational institutions in creating such effective and communicative teaching method in online mode as well as sufficient explanation on the materials. Another supportive factor toward an ideal online learning according to the respondents is the availability of facility and internet access. It is believed that online learning does requires such sophisticated instruments or digital tools to conduct the learning. Both teachers and students have to agree on a digital tool standard that will be employed in their learning, otherwise, the learning process cannot be conducted synchronously. Last but not least, an ideal online learning is a learning that successfully blends both face-to-face and online learning (blended learning). The students are interested to experience such combined mode of learning where materials and a set of learning documents are shared in advance, so they still have time to learn before conducting a discussion or debates in face-to-face meeting.

Table 3: Students' Expectation on ideal online learning

\begin{tabular}{lll}
\hline \multicolumn{1}{c}{ Expectation } & Frequency & Percentage \\
\hline Combined mode with a clear System & 20 & $18 \%$ \\
\hline Effective and creative teaching method and material & 50 & $45 \%$ \\
\hline Complete facilities and internet access & 35 & $31 \%$ \\
\hline No idea & 7 & $6 \%$ \\
\hline Total & 112 & $100 \%$ \\
\hline
\end{tabular}

\section{Conclusion}

The students clearly indicated that having an online learning through Google classroom brings more harms than good because they found it difficult to understand the materials due to the lack of explanation provided by the teachers. Furthermore, technical and financial problems are considered to be other factors that lead them to stand on negative point of view. In contrasts, those who have positivity in perceiving online learning argued that the students were benefited because they could access the material from home and they do not have to go to the university. Furthermore, its flexibility and effectiveness, particularly in learning amid the critical time of Covid-19, are the main reasons for them to stay positive with online learning through Google classroom. Furthermore, those who play safe by providing both positive and negative reasons are considered as neutral perception. These contradictive perceptions end the respondents' ideas on an ideal online learning. There are three main expectations toward an ideal online learning: an effective and creative method and material, such complete and available facilities and access as well as the combination of online and offline system.

\section{References}

Agung, A. S. S. N., Surtikanti, M. W., \& Quinones, C. A. (2020). Students' Perception of Online Learning during COVID-19 Pandemic: A Case Study on the English Students of STKIP Pamane Talino | Soshum: Jurnal Sosial dan Humaniora. Journal of Social Sciences and Humanities, 10(2). http://ojs.pnb.ac.id/index.php/SOSHUM/article/view/1316

Al-Maroof, R. A. S., \& Al-Emran, M. (2018). Students Acceptance of Google Classroom: An Exploratory Study using PLS-SEM Approach. International Journal of Emerging Technologies in Learning (IJET), 13(06), 112-123.

Apriyanti, D., Syarif, H., Ramadhan, S., Zaim, M., \& Agustina, A. (2019). Technology-Based Google Classroom In English Business Writing Class. 689-694. https://doi.org/10.2991/icla-18.2019.113

Aydin, S., Akkan, Y., Arpaz, E., \& Koparan, B. (2015). Online Learning in Vocational School: Focus on Students' Perceptions. Procedia - Social and Behavioral Sciences, 174, 3663-3667. https://doi.org/10.1016/j.sbspro.2015.01.1087

Bentley, Y., Selassie, H., \& Shegunshi, A. (2012). Design and Evaluation of Student-Focused eLearning. 10(1), 12.

Cheng, S.-L., \& Xie, K. (2021). Why college students procrastinate in online courses: A self-regulated learning perspective. The Internet and Higher Education, 50, 100807. https://doi.org/10.1016/j.iheduc.2021.100807

Dorf, R. C. (1969). Educational Technology. IEEE Transactions on Education, 12(1), 50-52. 
https://doi.org/10.1109/TE.1969.4320439

Dumford, A. D., \& Miller, A. L. (2018). Online learning in higher education: Exploring advantages and disadvantages for engagement. Journal of Computing in Higher Education, 30(3), 452-465. https://doi.org/10.1007/s12528-018-9179-z

Ellis, R. A., Ginns, P., \& Piggott, L. (2009). E-learning in higher education: Some key aspects and their relationship to approaches to study. Higher Education Research \& Development, 28(3), 303-318. https://doi.org/10.1080/07294360902839909

Fedynich, L., Bradley, K. S., \& Bradley, J. (2015). Graduate Students' Perceptions of Online Learning. Research in Higher Education Journal, 27. https://eric.ed.gov/?id=EJ1056187

Ferrer, J., Ringer, A., Saville, K., A Parris, M., \& Kashi, K. (2020). Students' motivation and engagement in higher education: The importance of attitude to online learning. Higher Education. https://doi.org/10.1007/s10734-020-00657-5

Goodyear, P., Salmon, G., Spector, J., Steeples, C., \& Tickner, S. (2001). Competencies for Online Teaching: A Special Report. Educational Technology Research and Development, 49(1), 21-24.

Henderson, M., Selwyn, N., \& Aston, R. (2017). What works and why? Student perceptions of 'useful' digital technology in university teaching and learning. Studies in Higher Education, 42(8), 1567-1579. https://doi.org/10.1080/03075079.2015.1007946

Kaufmann, R., \& Vallade, J. I. (2020). Exploring connections in the online learning environment: Student perceptions of rapport, climate, and loneliness. Interactive Learning Environments, $O(0)$, 1-15. https://doi.org/10.1080/10494820.2020.1749670

Kumar, J. A., \& Bervell, B. (2019). Improving English pronunciation via automatic speech recognition technology: International Journal of Innovation and Learning: Vol 25, No 2. Education and Information Technologies, 24, 1793-1817. https://doi. org/10.1007/s10639-018-09858-z.

Kumar, J. A., Bervell, B., \& Osman, S. (2020). Google classroom: Insights from Malaysian higher education students' and instructors' experiences. Education and Information Technologies, 25(5), 4175-4195. https://doi.org/10.1007/s10639-020-10163-x

Lin, S. M., \& Griffith, P. (2014). Impacts of Online Technology Use in Second Language Writing: A Review of the Literature. Reading Improvement, 51(3), 303-312.

Maqableh, M., \& Alia, M. (2021). Evaluation online learning of undergraduate students under lockdown amidst COVID-19 Pandemic: The online learning experience and students' satisfaction. Children and Youth Services Review, 128, 106160. https://doi.org/10.1016/j.childyouth.2021.106160

McConnell, D. (2018). E-learning in Chinese higher education: The view from inside. Higher Education, 75(6), 1031-1045. https://doi.org/10.1007/s10734-017-0183-4

Mishra, L., Gupta, T., \& Shree, A. (2020). Online teaching-learning in higher education during lockdown period of COVID-19 pandemic. International Journal of Educational Research Open, 100012. https://doi.org/10.1016/j.ijedro.2020.100012

Mulyani, M., Fidyati, F., Suryani, S., Suri, M., \& Halimatussakdiah, H. (2021). University students' perceptions through e-learning implementation during COVID-19 pandemic: Positive or negative features dominate? Studies in English Language and Education, 8(1), 197-211. https://doi.org/10.24815/siele.v8i1.17628

OECD. (2020). The impact of COVID-19 on student equity and inclusion-OECD. OECD. https://read.oecd-ilibrary.org/view/?ref=434_434914-59wd7ekj29\&title=The-impact-of-COVID19-on-student-equity-and-inclusion\&_ga=2.178529828.186574929.1626487407289770745.1626487407

Pullan, M. C. (2009). Student Support Services for Millennial Undergraduates. Journal of Educational Technology Systems, 38(2), 235-251. https://doi.org/10.2190/ET.38.2.k

Roehl, A., Reddy, S. L., \& Shannon, G. J. (2013). The Flipped Classroom: An Opportunity To Engage Millennial Students Through Active Learning Strategies. Journal of Family \& Consumer Sciences, 105(2), 44-49. https://doi.org/10.14307/JFCS105.2.12

Rojabi, A. R. (2020). Exploring EFL Students' Perception of Online Learning via Microsoft Teams: University Level in Indonesia. English Language Teaching Educational Journal, 3(2), 163. https://doi.org/10.12928/eltej.v3i2.2349

Rosita, N., Saun, S., \& Mairi, S. (2020). Google Classroom for Hybrid Learning in Senior High School. 7. 
Volume : 1 | Number 3 | December 2021 | E-ISSN : 2787-9482 |DOI: doi.org/ijeal.v1i3.1241

Subandi, S., Choirudin, C., Nizaruddin, N., \& Hermanita, H. (2018). Building Interactive Communication with Google Classroom. International Journal of Engineering and Technology(UAE), 7, 460-463. https://doi.org/10.14419/ijet.v7i2.13.18141

Syauqi, K., Munadi, S., \& Triyono, M. B. (2020). Students' Perceptions toward Vocational Education on Online Learning during the COVID-19 Pandemic. International Journal of Evaluation and Research in Education, 9(4), 881-886.

Van Wart, M., Ni, A., Medina, P., Canelon, J., Kordrostami, M., Zhang, J., \& Liu, Y. (2020). Integrating students' perspectives about online learning: A hierarchy of factors. International Journal of Educational Technology in Higher Education, 17(1), 53. https://doi.org/10.1186/s41239-020-00229-8

Werth, E. P., \& Werth, L. (2011). Effective Training for Millennial Students. Adult Learning, 22(3), 12-19. https://doi.org/10.1177/104515951102200302 